\title{
Rostificar o Acéfalo
}

\section{Tadeu Ribeiro Rodrigues ${ }^{1}$}

Resumo: O artigo propõe uma análise de imagens artísticas que suscitam as noções de rosto e cabeça como forma de tensionamento da representação humana. A partir de obras produzidas por Tunga, Man Ray e Francis Bacon, buscamos apresentar estratégias poéticas em torno das relações entre corpo e imagem.

Palavras-chave: corpo, imagem, rosto, cabeça

\section{Faciality for the acephalous}

Abstract: This work proposes an analysis of artistic images that evoke the notions of face and head in order to tense the human representation. From works of Tunga, Man Ray and Francis Bacon, we present some poetic strategies about the relations between body and image.

Keywords: body, image, face, head

Doutorando no Programa de Pós-graduação em Artes da Universidade do Estado do Rio de Janeiro, mestre em Estudos Contemporâneos das Artes pela Universidade Federal Fluminense e bacharel em História da Arte pela Universidade Federal do Rio de Janeiro. Vínculo institucional: PPGARTES/UERJ, R. São Francisco Xavier, 524 - Maracanã, Rio de Janeiro - RJ. E-mail: tadeu.ribeiro.rodrigues@gmail.com. ORCID: https://orcid.org/0000-0003-1032-0502. Lattes iD: http://lattes.cnpq.br/2919415153219064. Rio de Janeiro, Brasil 
"O que empreendemos é uma guerra", afirma Georges Bataille em A conjuração sagrada, texto inaugural da revista Acéphale (fig. 1), cuja primeira edição - de um total de cinco - é publicada em 1936. A revista é elaborada em torno da comunidade homônima, seu duplo, que resulta da colaboração de nomes como Georges Ambrosino, André Masson e Roger Caillois. Sob profunda influência e diálogo (être-avec) com a filosofia de Nietzsche, a angústia disparada pela véspera da guerra e a ascensão do nazi-fascismo na Europa, é nesse texto que Bataille apresenta o funcionamento do anti-deus acéfalo, fio condutor da experiência poética tecida nas páginas da publicação.

O homem escapou da sua cabeça como o condenado da prisão. Encontrou, para além dele mesmo, não Deus, que é a proibição do crime, mas um ser que ignora a proibição. Para além daquilo que sou, encontro um ser que me faz rir porque é sem cabeça, que me enche de angústia porque é feito de inocência e de crime: ele tem uma arma de ferro em sua mão esquerda, chamas semelhantes a um sagrado coração em sua mão direita. Reúne numa mesma erupção o Nascimento e a Morte. Não é um homem. Também não é um deus. Ele não é eu, mas é mais do que eu: seu ventre é o Dédalo em que se desgarrou a si mesmo, me desgarra com ele, e no qual me reencontro sendo ele, ou seja, monstro (BATAILLE, 2013, p.3).

O anti-homem evocado por Bataille tensiona a figura humana na medida em que recusa a cabeça, porção mais nobre do corpo segundo a anatomia clássica, sede das faculdades da razão e único fragmento corporal que contém em si todos os sentidos - visão, olfato, audição, paladar e tato. "A vida humana está exausta de servir de cabeça e de razão ao universo" (ibidem, p.3). O acéfalo - ainda que funcione aparentemente de modo análogo ao corpo-máquina da modernidade cartesiana, matéria inerte programável destitui, numa insurreição, seu núcleo de controle e domínio: a cabeça.

\begin{abstract}
A fascinação da liberdade se enfraqueceu quando a Terra produziu um ser que exige a necessidade como uma lei acima do universo. O homem, entretanto, permaneceu livre para não mais responder a necessidade alguma: ele é livre para se assemelhar a tudo aquilo que não é ele no universo. Pode descartar o pensamento de que é ele ou Deus que impede o resto das coisas de ser absurdo (idem).
\end{abstract}

A enunciação da possibilidade humana de "se assemelhar a tudo aquilo que não é ele no universo", se por um lado estabelece diálogo com a fabricação da noção de homem como ser plástico, moldável e adaptável durante o Renascimento ${ }^{1}$, carrega também consigo uma alternativa de dissolução. Sem 
a cabeça, desprovido de identidade homogênea, o acéfalo representa, no limite, o humano em sua vertigem última. Sem um rosto, elemento fundador da semelhança divina, o acéfalo é capaz de ser tudo aquilo a que ao humano regular é interdito. Nesse sentido, a gravura de Abraham Brosse que ilustra a capa do Leviatã de Hobbes (fig. 2), publicado em 1651, é notável para compreender o diagrama em que se inscreve a hierarquia anatômica: para defender o argumento de que o corpo social deve ser controlado pelo Estado, tal imagem apresenta um homem coroado que carrega numa das mãos uma espada e na outra um cetro. De seu ventre estendem-se montanhas que cercam uma cidade: a porção inferior do corpo é apresentada como matéria, posse, enquanto a cabeça contém a razão e legitimidade de um soberano. Cefalocracia: a cabeça como termo mais humano do corpo. A lógica que funda o Leviatã de Hobbes é, no entanto, pervertida no acéfalo de Bataille.

Figura 1 André Masson, Capa da revista Acéphale, 1936

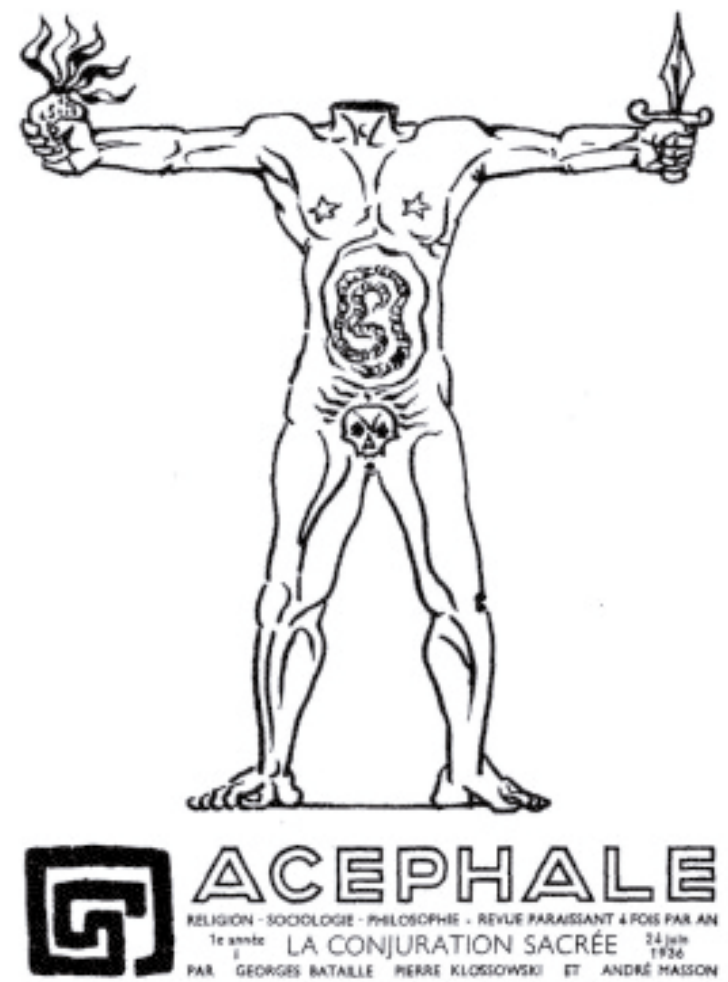

o filósofo italiano Giovanni Pico Della Mirandola concebe o homem como se indefinido, inacabado, plástico (SIBILIA, 2014). Essa definição compõe e reafirma a rede de discursos da modernidade nascente, na qual o homem ocupa lugar central na dinâmica do universo: tal homem monumental emancipa-se e expande sua vontade pelo planeta. 
Figura 2

Leviatã, gravura de Abraham Bosse

para o livro de

Thomas Hobbes,

1651

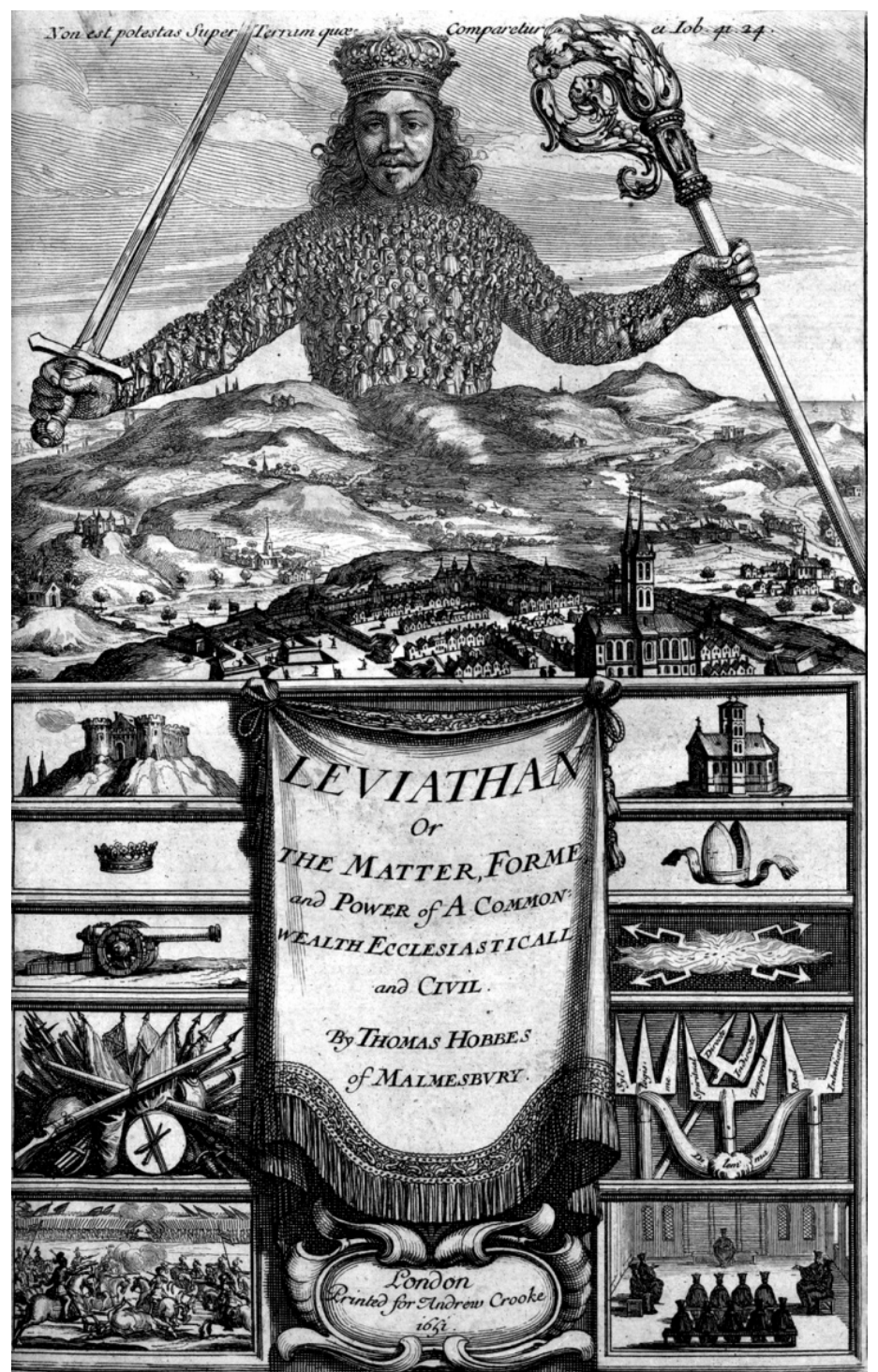

A certa altura da Odisseia, Homero narra o episódio no qual Ulisses, em sua viagem de retorno a Ítaca, "é orientado pela semideusa Circe para se proteger do irresistível canto das sereias, que atraíam e seduziam os navegantes, para depois destruí-los" (MARTINS, 2013, p.82). O herói, no entanto, escolhe ouvi-las, instruindo sua tripulação - que deveriam todos ter seus ouvidos vedados com cera - a amarrá-lo ao mastro da embarcação, tornando-o o único mortal a experimentar (e sobreviver) ao canto mítico que entorpecia os homens, levando-os a se perder nas águas. É a partir do poema épico grego que Tunga narra o encontro com sua própria cabeça, que flutuava numa poça formada pelas rochas de uma praia. Sua obra é atravessada pela ficção - por fios de ensaios ficcionais que constituem uma poética na qual texto e imagem se contaminam mutuamente na produção de sentidos -; "as remissões de Tunga ao campo da escrita documental, como recortes de jornais, relatórios de pesquisa, referências a falsas inscri- 
ções ou achados arqueológicos, são, na maior parte, simulações da 'verdade' científica" (idem). Em Semeando sereias (fig. 3), obra que se inicia em 1987, o artista constrói uma trama na qual uma sequência de fotografias é posta em contato com o texto nas páginas de seu livro Barroco de lírios, de 1997. Ao longo da série de imagens, vemos o artista aproximar-se da cabeça - prótese moldada a partir de sua própria -, circundá-la, tomá-la nas mãos alisando seus longos cabelos ruivos e, em seguida, girá-la sobre si para arremessá-la ao mar.

Figura 3

Tunga, Semeando sereias, 1987

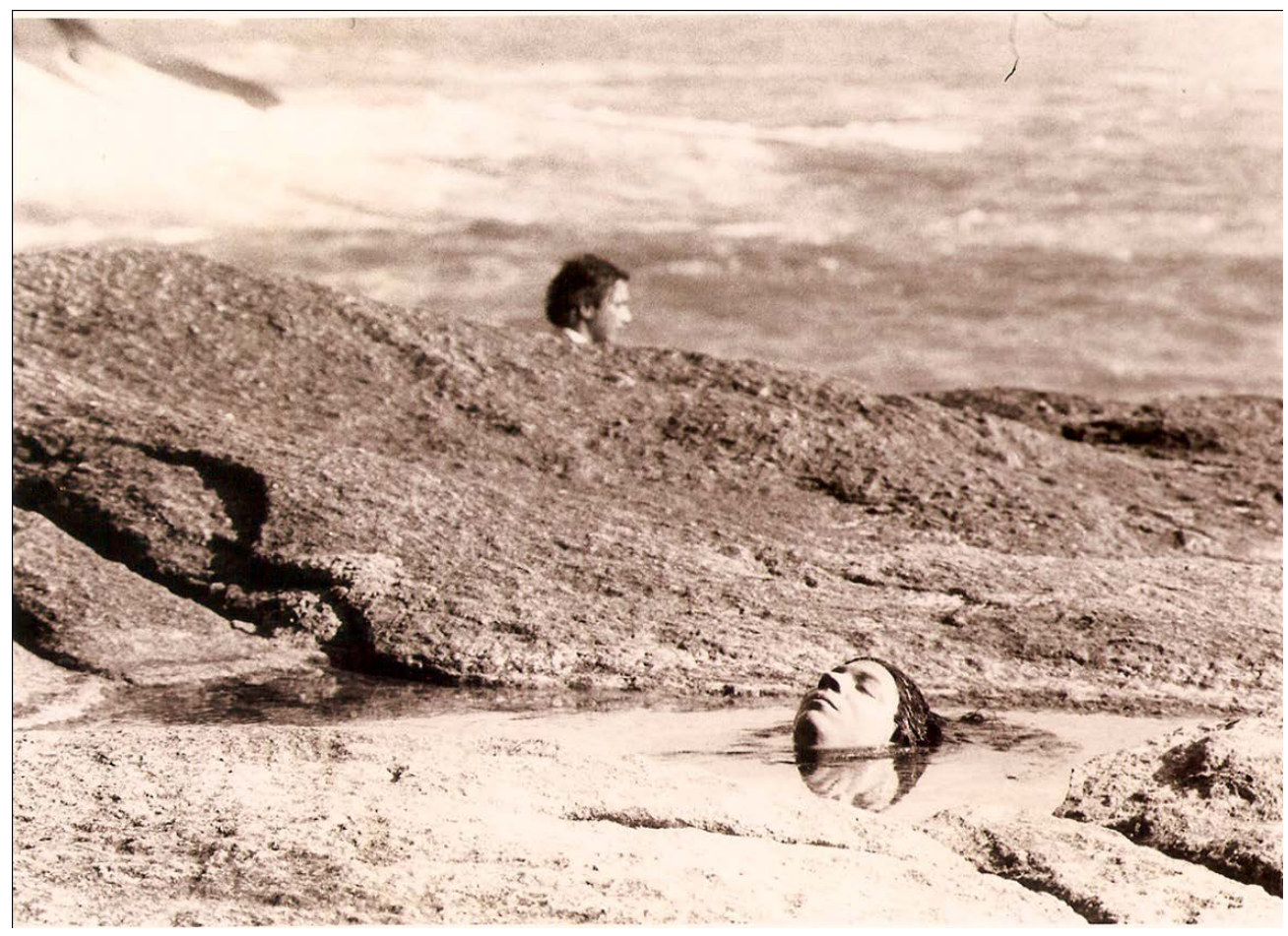

A ação de lançar a própria cabeça ao mar - atirando seu duplo à água informe -, evoca uma possibilidade acéfala, ou, antes, o despojamento simbólico da cabeça. Tunga cede à tentação do canto marinho e, num golpe, vai ao encontro dele para se perder. Ao deparar-se casualmente com sua própria face inerte na paisagem, o artista revisita as sereias de Homero, mas também o mito de Salomé e a cabeça decepada de João Batista. "Que fariam ali aqueles corpos?", indaga Tunga ao começar o texto. "Deveria ter deles me livrado, poderia não os ter olhado mas, uma vez lá, jamais os esquecer, era tarde" (1997, p.288). Como num reverso "encontro fortuito, sobre uma mesa de dissecação, entre uma máquina de costura e um guarda-chuva" (LAUTRÉAMONT apud MORAES, 2012, p. 44) proposto por Lautréamont em Les Chants de Maldoror, mote dos surrealistas, Tunga encontra não um objeto aleatório, mas ele mesmo. 
Dirigi-me à beira da baía rochosa para o espetáculo matinal. Excessos etílicos da noite davam-me a impressão de estar inteiramente encharcado. O leve amarelar do sol ainda morno me propôs um adequado raio, proveniente do meu corpo. Pus-me portanto a urinar um poderoso fluxo e a sentir tal fluxo como elétrico âmbar aflorando de mim. Ruidosamente este se dissolvia em uma poça abaixo, num pequeno lago, resíduo de águas marinhas, sobre a praia lítica. Levemente ofuscado pude perceber que em tal lago flutuava esférico um objeto. Descendo alguns passos me aproximei paulatinamente daquela salobra água, onde entrei, até os joelhos. Meu propósito era reconhecer o rotundo objeto. Um frisson magnético percorreu minha pele. O objeto que encontrara era a minha própria cabeça decepada (TUNGA, 1997, p.305).

Após tomar nas mãos aquele "mórbido troféu", decide lançá-lo "ao mar, para que ali encontrasse seu adequado derradeiro sepulcro", prossegue a narrativa de Tunga. $O$ artista observa a cabeça flutuante, cujos longos fios de cabelo aderem à textura rochosa, e vai ele próprio à água para desembaraçar-lhe da encosta. Nesse momento, avista um corpo "absolutamente íntegro" no movimento das ondas, não distante do primeiro objeto, e que, no entanto, não era o dele. Tratava-se de um corpo feminino. O intercâmbio e recombinação das partes do corpo, desencaixadas de seu todo, abre sua poética à possibilidade de perder-se: "se no labirinto o homem se perde, ali também ele se reencontra, mas 'sendo monstro'" (MORAES, 2012, p.220). A mitologia é farta em personagens que conduzem o humano à perda de si. Como as sereias de Homero e Tunga, além da Medusa, que "precipita igualmente o ser humano no horror que compõe seu 'outro rosto'" (Ibidem, p.220), a figura do Minotauro, encerrado em seu labirinto, evoca o caminho do herói que é lançado à perda. Tal evocação é operada por Man Ray em sua fotografia de 1935, Le Minotaure (fig. 4), publicada na revista homônima editada pelos surrealistas André Bréton e Pierre Mabille.

Destacando-se do fundo negro, vê-se um torso feminino entrecortado pelas sombras, do qual a cabeça não está visível. O gesto da mulher - cujos braços estão levantados sobre os ombros -, aliado ao posicionamento de luzes, compõe um jogo gestáltico no qual vemos a cabeça de um touro. Acima da cavidade do ventre, onde forma-se uma grande boca, os mamilos funcionam como olhos e os braços ganham o aspecto de chifres: "a cabeça é completamente tragada pela escuridão do fundo; dela, nada sabemos" (Ibidem, p.220). O humano, em sua vertigem, assume um devir-touro - mulher-minotauro, corpo-monstro -, confundindo-se, pelas luzes, numa besta. A imagem parece entrever, no limite, a impossibilidade da decodificação do rosto como algo dado, estático:

Mas tampouco estão completamente prontos os rostos concretos que poderíamos nos atribuir. Os rostos concretos nascem de uma máquina abstrata de rostidade, que irá produzi-los (...). A máquina abstrata surge quando não a esperamos, nos mean- 
dros de um adormecimento, de um estado crepuscular, de uma alucinação, de uma experiência de física curiosa... A cabeça está compreendida no corpo, mas não o rosto. O rosto é uma superfície: traços, linhas, rugas do rosto, rosto comprido, quadrado, triangular; o rosto é um mapa, mesmo se aplicado sobre um volume, envolvendo-o, mesmo se cercando e margeando cavidades que não existem mais senão como buracos. Mesmo humana, a cabeça não é forçosamente um rosto. $O$ rosto só se produz quando a cabeça deixa de fazer parte do corpo, quando para de ser codificada pelo corpo, quando ela mesma para de ter um código corporal plurívoco multidimensional - quando o corpo, incluindo a cabeça, se encontra descodificado e deve ser sobrecodificado por algo que denominaremos Rosto (DELEUZE; GUATTARI, 2012, p.37-39, grifo do autor).

Figura 3

Man Ray, Le minotaure, 1935

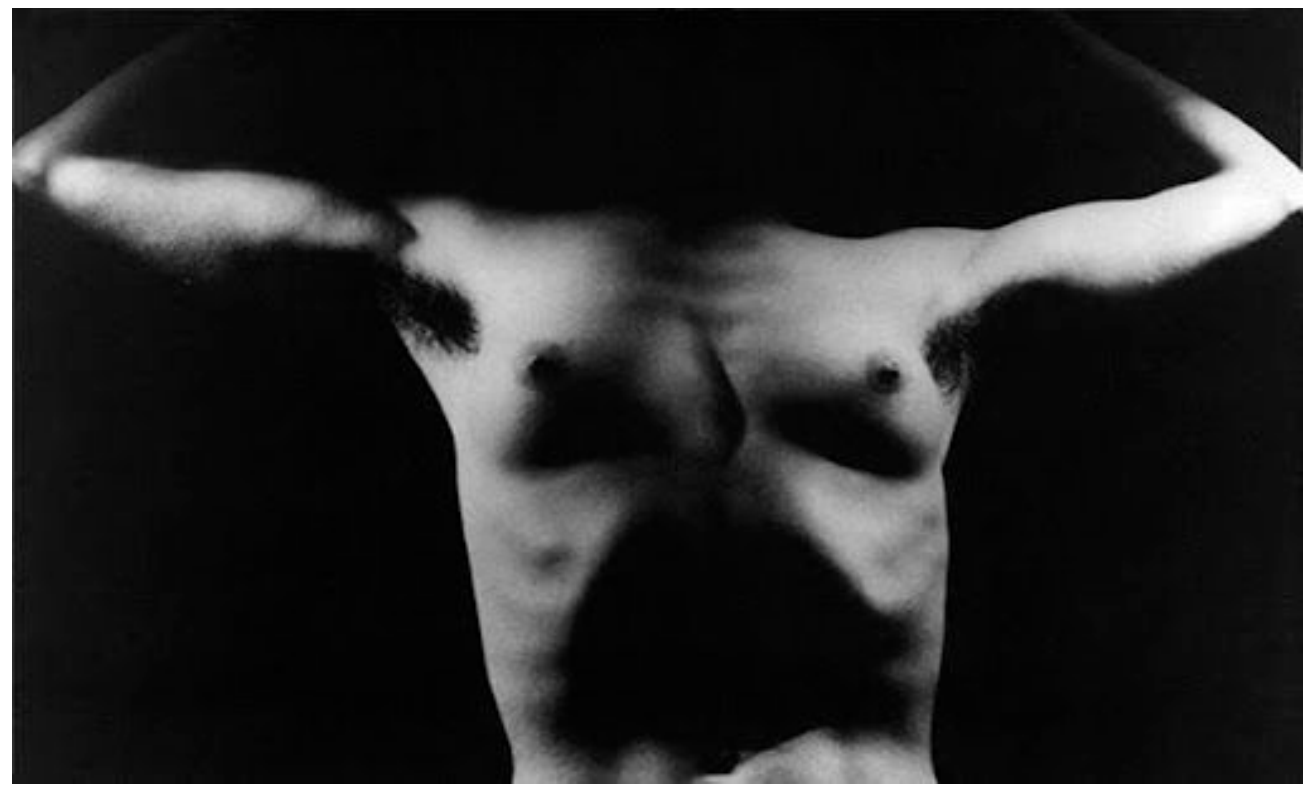

A proposição de Deleuze e Guattari segundo a qual cabeça e rosto não coincidem imediatamente pode orientar a observação de determinadas experiências de Man Ray. Na imagem seguinte (fig. 5), um volume de massa informe irrompe do fundo negro da imagem em verticalidade ascendente. Apesar de seu aspecto orgânico - a partir do qual percebemos tratar-se de um corpo humano -, a pirâmide formada sobre a superfície fotográfica causa estranhamento e desorientação. Em Anatomies, deparamo-nos com uma possibilidade antropomórfica vertiginosa, uma cartografia redesenhada. As operações de aproximação, deformação e dilatação de um ângulo anatômico ativam imagens outras para o corpo; há aqui a insurgência, por meio da imagem, de um corpo deslocado de sua estrutura tradicional de representação, uma corporeidade alternativa à hierarquia lógica dos órgãos, ao plano de inscrição esquadrinhado do corpo no qual cada parte permanece fixa em seu lugar para desempenhar sua função de legibilidade e funcionamento orgânico. O pescoço de Anatomies estira-se 
para trás, eleva o queixo e faz deslizar a mancha gráfica em direção ao colo da figura, como no enquadramento de um busto - gênero privilegiado da retratística - ali onde deveria haver um rosto.

Cabeça, Nova York (fig. 6), também de Man Ray, joga com a mesma operação de inversão da verticalidade - não para encontrar uma alternativa horizontal conciliadora, mas a partir da inversão das extremidades. De um conjunto de volutas formadas pelos cabelos da figura na base da fotografia, surge um rosto invertido, outra possibilidade antropomórfica piramidal

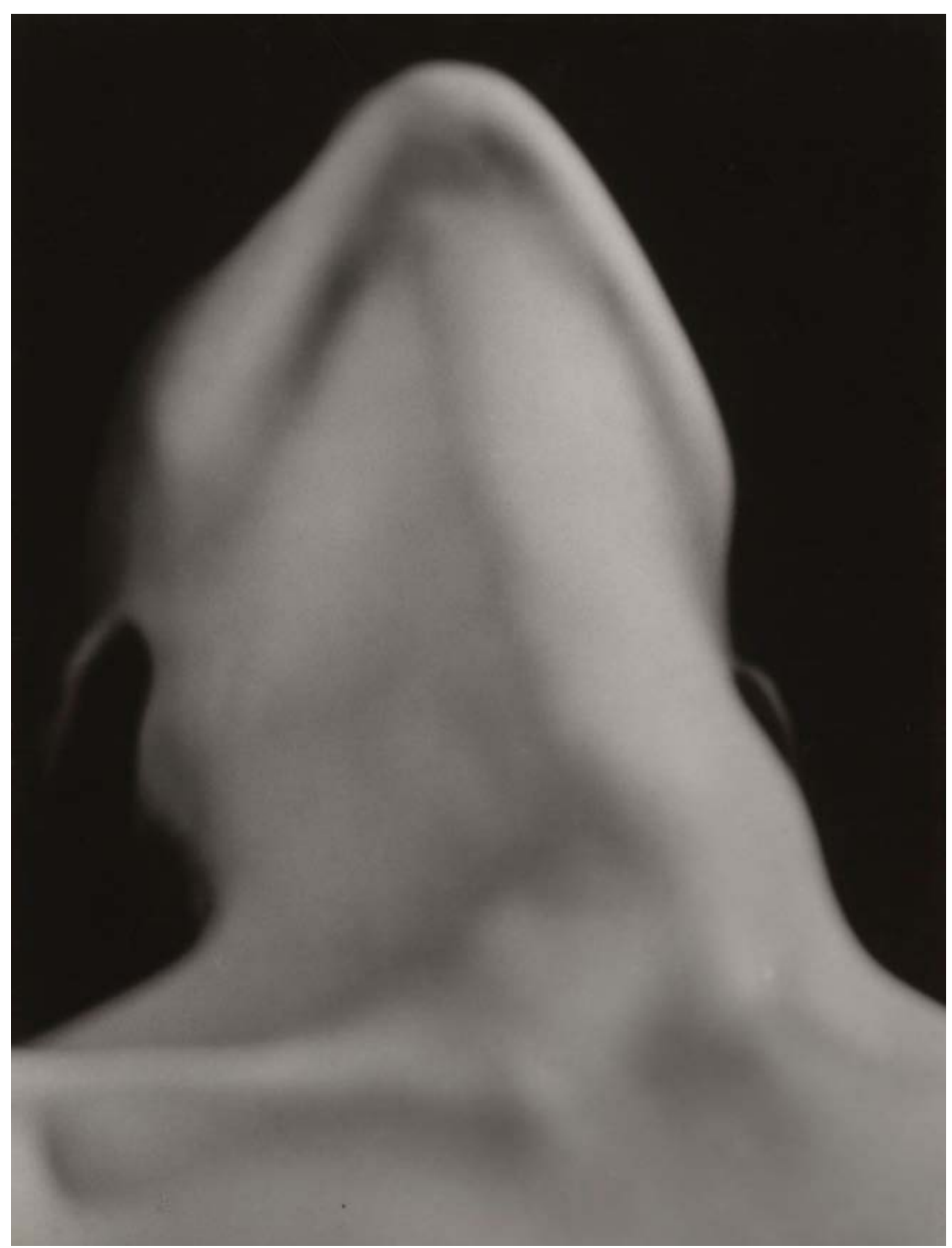


Figura 6 Man Ray, Anatomies, 1929

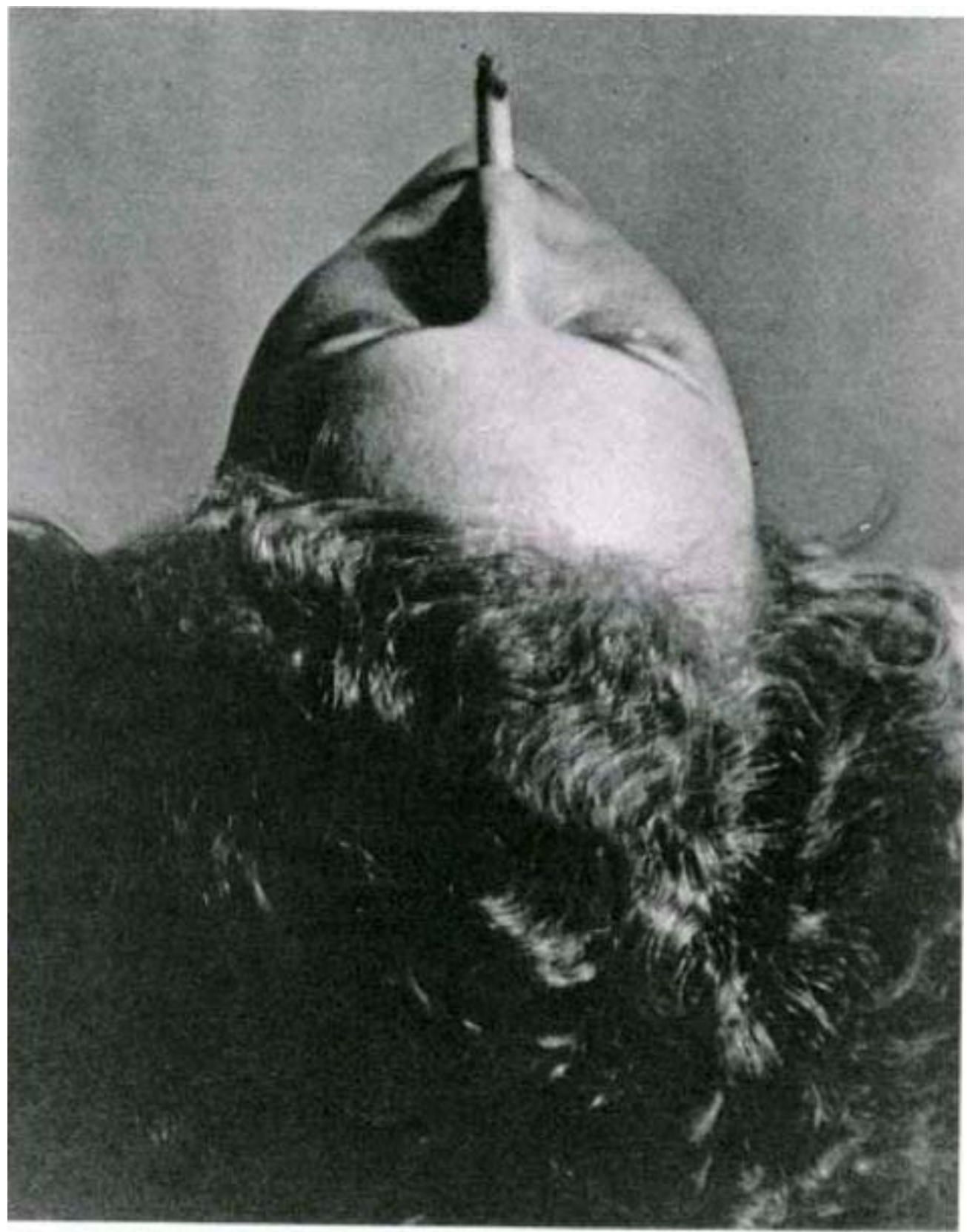

e estranhamente familiar. No cume do triângulo, um cigarro é sustentado pela boca: a fumaça, por fim, dissipa-se no espaço acinzentado, fabricando e dissolvendo o fundo.

Esse conjunto de fotografias, produzidas entre as décadas de 1920 e 1930 no contexto de experimentações dadaístas e surrealistas, tem em comum uma série de operações na imagem - pirâmide, inversão, ângulo fechado - cujo funcionamento gravita em torno de uma desfamiliarização do olhar na direção de uma desnaturalização radical do corpo. A partir do embaraIhamento dos modos de olhar e representar, Man Ray propõe um tensiona- 
mento das evidências de um corpo presumidamente natural, dado, assim como das próprias estruturas que sustentam a fabricação de imagens e formas. Rosalind Krauss ${ }^{2}$, ao analisar essa produção, aponta a noção de informe $e^{3}$ como possibilidade de olhar essas fotografias. Para isso, evoca a imagem do cigarro como disparador dessa fricção das formas: numa parábola narrada por Dalí, um homem distraído confunde a ponta ígnea de um cigarro aceso com uma estrela no céu noturno. Em seguida, dizem-Ihe que "a ponta desse cigarro é na verdade o único ponto visível de um imenso objeto 'psico-atmosférico-anamórfico'" (KRAUSS, 2002, p.171).

O estranhamento disparado por esse caráter "psico-atmosférico-anamórfico" do olhar atravessa as inquietações frente à imagem propostas em torno do surrealismo. As associações produzidas na vigília e no delírio, o acaso (por vezes intencional) do encontro entre imagens, as permutações possíveis entre objetos abrem o campo para um universo onde a preocupação está menos nos termos que nas relações, como num dicionário em que se desenha um mapa entre as palavras e cujo sentido só é ativado nesse encontro, nunca de maneira absoluta e universal. A noção de informe, tal como é propostapor Bataille, oferece uma tarefa para os termos, um funcionamento como estratégia para um dicionário. O corpo surge reorganizado como coisa colossal da qual só vemos uma ínfima parte em delírio. O antropomorfismo dessas obras, assim como as formas em geral, não é banido da representação, mas, antes, pervertido e dissecado, expondo-se suas arbitrariedades e hierarquias: o informe não é a ausência da forma, mas seu tensionamento, inflamação e questionamento. Não basta aniquilar e suprimir definitivamente as fronteiras que separam as coisas, mas permutá-las, atravessá-las, enganá-las. Nesse sentido, Krauss afirma que a "tarefa" do informe é menos transcender que transgredir.

2 Rosalind Krauss retoma, na década de 1990, a produção de Bataille na revista Documents: no texto Corpus Delicti, da obra O Fotográfico, a autora evoca a noção de informe para pensar um conjunto de fotografias modernistas; em 1996, em colaboração com Yve-Alain Bois, produz a exposição L'informe: mode d'emploi.

3 O termo informe surge numa seção da revista Documents, editada por Bataille, em 1929: o Dicionário Crítico. O verbete se inicia dizendo: “Um dicionário começaria a partir do momento em que não fornecesse mais o sentido, mas as tarefas das palavras. Assim, informe não é apenas um adjetivo tendo tal ou tal sentido, mas um termo que serve para desclassificar, exigindo geralmente que cada coisa tenha sua forma" (BATAILLE, 2018). 
Hal Foster chama atenção para outros pontos relevantes acerca da produção fotográfica em torno do surrealismo: o circuito das representações antropomórficas concede lugares distintos para figuras masculinas e femininas. Enquanto a modernidade forja um corpo ético e monumental para determinada possibilidade de homem - corpo que ilustra a soberania, a razão e o Estado -, a representação de mulheres, continuamente apagadas como criadoras autônomas, recai sob o signo da posse, matéria inerte e lasciva à disposição do olhar masculino. Nessas fotografias, embora se manifeste a reivindicação de uma libertação sexual (e o corpo feminino surge como ponto central desse fenômeno), a predominância ainda é de artistas homens. O ponto de inflexão, sugere Foster, está na maneira como essa representação é elaborada: a ambivalência do olhar feminino e a ansiedade disparada no observador são analisadas pelo autor sob o viés do pavor da castração. O olhar é um dos principais eixos de gravitação dessa ambiguidade nas artes e na psicanálise: no texto Unheimlich (traduzido em português como estranho, inquietante), Freud retoma um conto de Hoffmann no qual o olhar está intimamente ligado ao medo da perda masculina, do mesmo modo que em A história do olho, de Bataille, os olhos são metáfora de ovos, e as lágrimas, o esperma. A fetichização do corpo feminino, no entanto, evoca o perigo da castração de forma ambivalente: se, por um lado, parece estabelecer uma conciliação, de outro, funciona como um memorial da angústia masculina. Nessas fotografias, o corpo da mulher aparece mutilado em seu antropomorfismo: pernas e braços cortados, cabeças escondidas, ângulos desfigurados. O corpo histérico redistribui-se em novos arranjos, como nas poupées de Bellmer, traçando estruturas e mapas não lineares para a experiência corporal. Nessa monstruosidade, o olhar é veículo do terror.

Figura 6

Francis Bacon,

Study for Three

Heads, 1967
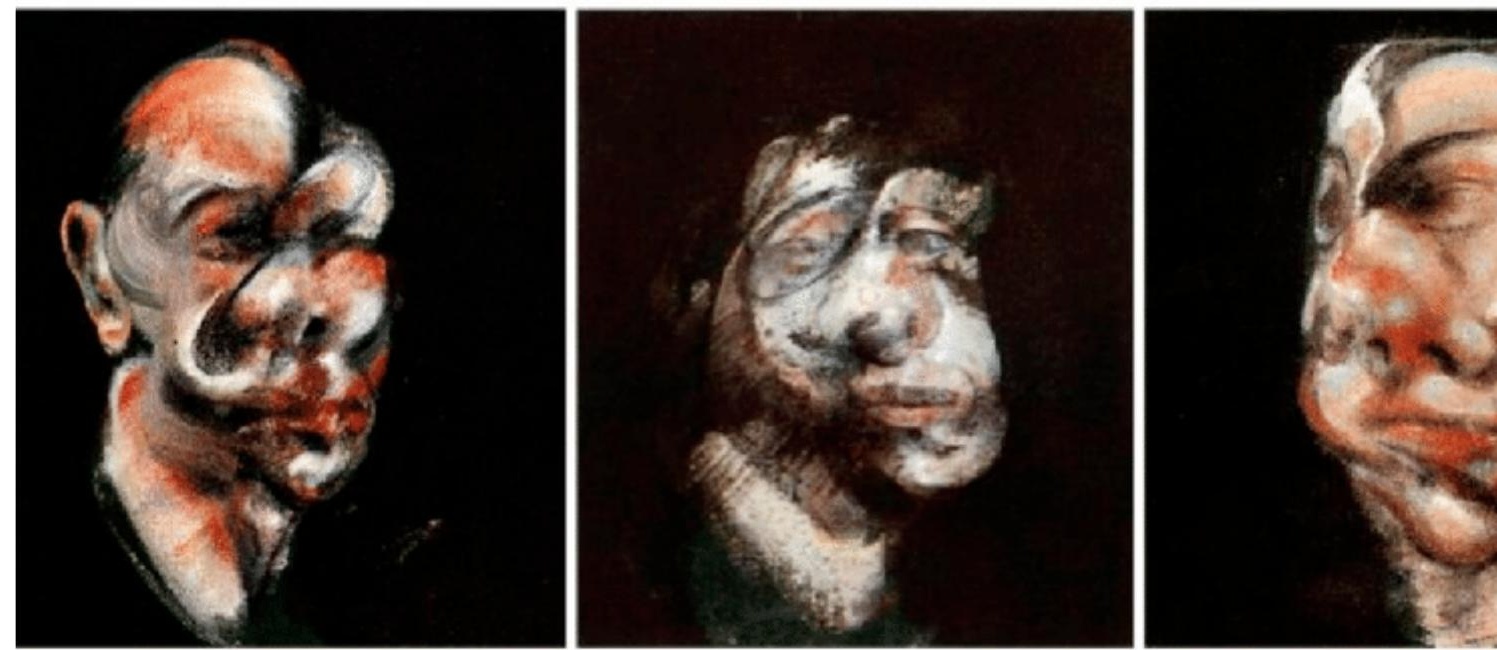
Em Lógica da Sensação, Deleuze analisa a produção de Francis Bacon (fig. 7) a partir de suas operações de desfiguração dos corpos na imagem. $\mathrm{Na}$ poética do pintor, as figuras - de modo distinto da fotografia surrealista - surgem na superfície bidimensional da tela e se constroem num plano de violento encontro com o fundo, absorvendo-o, sendo absorvidas, vomitando-o. "É um procedimento muito simples que consiste em isolar a Figura", afirma Deleuze. "O importante é que [os procedimentos] não limitam a Figura à imobilidade; pelo contrário, eles tornam sensível uma espécie de encaminhamento, de exploração da Figura em seu lugar, ou sobre si mesma" (2007, p.12). No sistema de Bacon, é preciso isolar a figura para reverter seu caráter narrativo, ilustrativo e propriamente figurativo. A pintura, nesse caso, busca as potências do acontecimento, das forças e intensidades.

\begin{abstract}
A pintura não tem nem modelo a representar, nem história a contar [...]. O figurativo (a representação) implica, de fato, em relacionar uma imagem a um objeto e busca ilustrá-lo; mas ela implica também a relação de uma imagem com outras imagens em um conjunto composto que oferece precisamente para cada um o seu objeto. A narrativa é o correlato da ilustração. Entre duas figuras, há sempre uma história que se insinua ou tende a se insinuar, para animar o conjunto ilustrado (DELEUZE, 2007, p.12).
\end{abstract}

Deleuze identifica na obra de Bacon uma potente proposição poética que radicaliza experiências anteriores na pintura: o corpo se manifesta nessas imagens como campo de indiscernibilidade e indecisão; seus contornos porosos e escorregadios confundem-se com o espaço-fundo. Corpos que buscam deslizar pelo buraco de uma pia ou se reorganizar precariamente na estrutura cúbica ou circular da tela. Nesse sentido, Bacon estabelece uma desconcertante interlocução com o gênero do retrato. Para Deleuze, o pintor é antes de tudo um retratista que pinta cabeças e não rostos, num projeto de "desfazer o rosto, encontrar ou fazer surgir uma cabeça sob um rosto" (ibid., p.28). O rosto, lugar privilegiado da identidade, é desarticulado e dissolvido em forças de intensidade, devires e desfigurações.

Ao propor o funcionamento de uma rostidade que não coincide com a cabeça, a figura do acéfalo de Masson na capa de Acéphale (assim como a fotografia do Minotaure de Man Ray), dispara uma potência de rosto que ultrapassa a visualidade da cabeça. O conjunto antropomórfico do acéfalo reinventa e ficciona uma rostidade violenta e redistribuída entre o nó dos intestinos no ventre, as estrelas que ocupam o lugar de mamilos, o crânio genital e os braços abertos em posição cruciforme. $O$ acéfalo olha sem os olhos, é afetado sem o coração, metaboliza as intensidades nos filamentos das tripas.

O corpo que vibra nas imagens de Bacon ativa potências - "esta uni- 
dade rítmica do sentido", segundo Deleuze - na medida em que ultrapassa o organismo e transgride sua forma, a Figura. Para elaborar essa questão, Deleuze e Guattari recorrem a Antonin Artaud: "O corpo é o corpo, Ele é sozinho e não precisa de órgãos. O corpo nunca é um organismo. Os organismos são inimigos dos corpos" (ARTAUD apud DELEUZE, 2007, p.51). Na transmissão radiofônica Para acabar com o juízo de Deus, de 1947, Artaud opera um levante contra o organismo estratificado - subjetivado em sua sujeição, significado em seu juízo e organizado em sua interpretação. O funcionamento de um corpo sem órgãos, no entanto, se opõe menos aos órgãos que ao organismo que sedimenta, territorializa, coagula e "Ihe impõe formas, funções, ligações, organizações dominantes e hierarquizadas, transcendências organizadas para extrair um trabalho útil" (DELEUZE, 2012, p.21). Corpo-junkie, corpo-capital, corpo-sujeitado. Quando Artaud propõe a experiência de um corpo sem órgãos, trata-se de um convite não à recusa dos órgãos propriamente, mas à organização a qual denominamos organismo. O inimigo é o organismo-dicionário, no qual cada órgão perde suas potências de intensidade (as potências de um corpo intensivo) para dar lugar à mecânica dos sentidos fixos e utilitários. Na vertiginosa impossibilidade de conformação num corpo docilizado, produtivo e burguês que fabrica um organismo produtivo e neurótico, Artaud conjura o corpo acéfalo: "a noção de desejo é um corpo acéfalo... um estado de graça em tudo semelhante à ferocidade dos micróbios é um corpo acéfalo" (2012, p.18-19). O acéfalo impõe uma ruptura com a organização racional do organismo, vê por meios não-visuais, escuta em descolamento ao ouvido. Em Mil Platôs, Deleuze e Guattari exploram tais possibilidades:

[...] do corpo hipocondríaco, cujos órgãos são destruídos [...], A Senhorita X afirma que não tem mais cérebro nem nervos nem peito nem estômago nem tripas, somente lhe restam a pele e os ossos do corpo desorganizado [...]; -do corpo paranoico, cujos órgãos não cessam de ser atacados por influências, mas também restaurados por energias exteriores ('ele viveu muito tempo sem estômago, sem intestinos, quase sem pulmões, o esôfago dilacerado, sem bexiga, as costelas quebradas, ele havia comido parcialmente sua própria laringe, e assim por diante, mas os milagres divinos haviam sempre regenerado novamente aquilo que havia sido destruído...'); - do corpo esquizo, acedendo uma luta interior ativa que ele mesmo desenvolve contra os órgãos, chegando à catatonia; e depois o corpo drogado, esquizo experimental: 'o organismo humano é de uma ineficácia gritante; em vez de uma boca e de um ânus que correm o risco de se arruinar, por que não possuir um único orifício polivalente para a alimentação e a defecação' [...]; - do corpo masoquista, [...] ele se deixa costurar por seu sádico [...], deixa-se suspender para interromper o exercício dos órgãos, esfolar como se os órgãos se colassem na pele, enrabar, asfixiar para que tudo seja selado e bem fechado (DELEUZE, GUATTARI, 2012, p.12, grifos do autor).

Bataille afirma, num breve texto de 1929, que "o dedão do pé é a parte mais humana do corpo humano, no sentido de que nenhum outro elemen- 
to desse corpo é tão diferenciado do elemento correspondente do macaco antropoide" (2018, p.119). Responsável pela sustentação da postura ereta "de que o homem tanto se orgulha", o dedão distingue o funcionamento anatômico humano dos primatas arborícolas, facultando-o a locomoção no chão como bípede. Em oposição à cabeça - elevada ao céu verticalmente - os pés mantêm-se na lama. Bataille argumenta, em seguida, que o fluxo sanguíneo no corpo é equivalente, em quantidade, para baixo e para cima: "a vida humana é erroneamente vista como uma elevação [...], com os pés na lama mas a cabeça mais ou menos na luz, os homens imaginam obstinadamente um fluxo que os elevaria sem retorno ao espaço puro" (ibidem, p.120). O dedão do pé, grotesco e disforme, permite que possamos nos levantar em direção à ideia e, no entanto, "a vida humana comporta de fato a fúria de saber que se trata de um movimento de vai-e-vem da sujeira ao ideal e do ideal à sujeira, fúria que é fácil fazer passar para um órgão tão baixo quanto um pé" (ibidem, p.120). Em Le gros orteil, o autor indica um de seus procedimentos poéticos que irá reverberar ao longo de sua obra: o ataque à verticalidade antropomórfica, isto é, a reversão da monumentalidade idealista do humano. A cabeça - e, por conseguinte, o rosto - situa-se, fisiológica e hierarquicamente, em oposição ao dedão. A humanidade presente no rosto opõe-se brutalmente à materialidade funcional do pé. Bataille, no entanto, aponta para o sentido contrário ao da anatomia clássica: vê, no dedão, a porção que caracteriza nossa humanidade.

Em meio à multidão de corpos que, como capilaridades, criam-se e são criados na fricção entre o real e a elaboração poética, o século XX fez surgir antropomorfismos que tensionam a figuração clássica, reclamando espaço para outras possibilidades de corpos e imagens. Entre cabeças e rostos que desconcertam a legibilidade dos corpos, entrevemos outras experiências possíveis. O corpo, em sua multiplicidade de sentidos, é a unidade imediata do pensamento humano para fabricar o universo: as regras que regem a ordem de uma cosmologia antropomórfica dizem respeito não só à representação humana, mas, antes, à formulação de um mundo. "Negar o possível para imaginar o impossível: o projeto de Bataille, ao mesmo tempo em que remete aos fundamentos da liberdade da imaginação, resume o sentido último de seu antropomorfismo dilacerado, insistindo em repensar o homem a partir do nada", nos diz Eliane Robert Moraes (2012, p. 227). Reconstruir o corpo a partir do rosto ou da perda da cabeça, pensá-lo como algo que não é dado ou natural, presume a violência de um desantropomorfismo que jamais se conclui. 


\section{Referências}

BATAILLE, Georges. Acéphale (4 vol.). Florianópolis: Cultura e Barbárie, 2013.

Documents: Georges Bataille. Florianópolis: Cultura e Barbárie, 2018.

DELEUZE, Gilles. Francis Bacon: lógica da sensação. Rio de Janeiro: Jorge Zahar, 2007. .; GUATTARI, Félix. Mil platôs:capitalismo e esquizofrenia 2, v.3. São Paulo: Editora 34, 2012.

FOSTER, Hal. Prosthetic Gods. Massachusetts Institute of Technology, 2004.

KRAUSS, Rosalind. O fotográfico. Barcelona: Editorial Gustavo Gili, 2002.

MARTINS, Marta. Narrativas ficcionais de Tunga. Rio de Janeiro: Apicuri, 2013.

MORAES, Eliane Robert. O Corpo Impossível. São Paulo: Iluminuras, 2012.

SIBILIA, Paula. O homem pós-orgânico: a alquimia dos corpos e das almas à luz das tecnologias digitais. Rio de Janeiro: Contraponto, 2015.

TUNGA. Barroco de lírios. São Paulo: Cosac Naify, 1997. 